\title{
Unusual specificity of the androgen receptor in the human prostate tumor cell line LNCaP: high affinity for progestagenic and estrogenic steroids
}

\author{
Jos Veldscholte ${ }^{1}$, Marleen M. Voorhorst-Ogink ${ }^{1}$, Joan Bolt-de Vries ${ }^{1}$, \\ Henri C.J. van Rooij ${ }^{2}$, Jan Trapman ${ }^{2}$, and Eppo Mulder ${ }^{1}$ \\ ${ }^{2}$ Department of Biochemistry II and ${ }^{2}$ Department of Pathology, Erasmus University Rotterdam, Rotterdam (The Netherlands)
}

(Received 21 November 1989)

Key words: Androgen receptor; LNCaP tumor cell; Steroid binding; Tumor cell; specificity; (Human prostatic carcinoma)

LNCaP tumor cells, derived from a metastatic lesion of a human prostatic carcinoma, are androgen-sensitive in cell culture. Although increase in growth rate is observed with low doses of progestagens or estradiol, these cells contain exclusively androgen receptors. In the present study the binding affinity of different ligands for both non-DNA- and DNA-binding (transformed) forms of the androgen receptor were analyzed. The cytosolic (non-transformed) form of the receptor displayed an abnormal high affinity for progestagens and estradiol when compared with the cytosolic androgen receptor from other sources. Subsequently the non-transformed forms of the androgen receptor obtained from LNCaP cell nuclei was studied. A high binding affinity was found not only for dihydrotestosterone, but also for progesterone and the synthetic progestagen $\mathbf{R 5 0 2 0}$ (relative binding affinity $42 \%$ and $10 \%$ of dihydrotestosterone). The binding characteristics of the transformed androgen receptor were examined in intact cells at $37^{\circ} \mathrm{C}$. LNCaP cells were compared in this respect with COS cells containing the cloned human androgen receptor, normal human skin fibroblasts and PC3 (prostate) and NHIK (cervix) human tumor cell lines. The affinity of the transformed androgen receptors for the progestagen R5020 in LNCaP cells was significantly higher than in the other cell systems, although the differences were less pronounced than for the non-transformed receptor form. In conclusion: the LNCaP tumor cells contain an androgen receptor with an abnormal binding site. This might be due to a mutation and / or a post-transcriptional effect.

\section{Introduction}

The actions of steroid hormones on their target cells are mediated by specific receptor proteins. The hormone binds to the receptor and the receptor is transformed to a DNA-binding form with a high affinity for the hormone-responsive enhancer elements of the hormone-responsive genes. Binding of the transformed receptor to these enhancer elements is an essential step in transcriptional activation. The specificity of hormonal action is accomplished both by the specific recognition of the enhancer element by the DNA-binding part of the receptor and by the specificty of the hormone-receptor interaction, determined by the steroid-binding part of the receptor. [1,2].

Correspondence: J. Veldscholte, Department of Biochemistry II, Erasmus University Rotterdam, P.O. Box 1738, 3000 DR Rotterdam, The Netherlands.
LNCaP tumor cells derived from a metastatic lesion of a human prostatic carcinoma contain androgen receptors and respond to androgens with growth in cell culture [3,4]. In addition, increase in growth rate is observed in the presence of low doses of estrogens [3,5] and progestagens [6], but these cells do not contain progestagen [6] or estrogen receptors [4], as has been shown in our laboratory previously with specific antibodies against these receptor proteins. Additional proof for the absence of progesterone receptors was found in studies with the synthetic ligand R1881, which has equal affinity for both androgen and progestagen receptors [7]. Specific antibodies against the androgen receptor complexed with all R1881 bound to receptors, thereby demonstrating the absence of RI881 binding to progesterone receptors [8].

Preliminary experiments indicated that the cytosolic androgen receptor had a high affinity for both progestagens and estrogens. [6]. Cytosolic receptor preparations, however, contain only the non-DNA binding 
form of the receptor and are often exposed to proteolytic breakdown or are contaminated with other steroid-binding proteins as sex-hormone-binding globulin or lower affinity binders. Therefore, we studied the steroid binding specificity of the unoccupied androgen receptor in $\mathrm{LNCaP}$ cells in intact isolation nuclei at $4^{\circ} \mathrm{C}$. Because the receptor has to go through a multi-step transformation process, before hormone-sensitive genes are activated, the steroid-binding affinity of the nuclear transformed receptor was also analyzed in intact cells incubated with steroids at the physiological temperature. The affinity of the androgen receptor for the progestagen R5020 in these cells was compared with the affinity of the androgen receptor in three other human cell types and with androgen receptors obtained from COS cells transfected with androgen receptor CDNA [9].

We demonstrate that the androgen receptor of LNCaP prostate tumor cells has an unusual high affinity for several steroids and especially for progestagens.

\section{Experimental}

\section{Materials}

$\left[{ }^{3} \mathrm{H}\right] \mathrm{R} 1881 \quad\left({ }^{3} \mathrm{H}\right.$-labeled $17 \beta$-hydroxy-17 $\alpha$-methylestra-4,9,11-trien-3-one), s.a., $87 \mathrm{Ci} / \mathrm{mmol}$, and unlabeled R1881 and R5020 (17a,21-dimethyl-19norpregna-4,9-dione-3,-20-dione) were purchased from New England Nuclear (Boston, U.S.A.). $\left[1,2,6,7-{ }^{3} \mathrm{H}\right]$ Progesterone, s.a., $84 \mathrm{Ci} / \mathrm{mmol}$, was obtained from Amersham (U.K.). Triamcinolone acetonide ( $9 \alpha$-fluoro$11 \beta-16 \alpha, 17,21$-tetrahydroxy-1,4-pregnadiene-3,20-dione 16,17 -acetonide) was from Sigma (St. Louis, U.S.A.). All other steroids were purchased from Steraloids (Wilton, U.S.A.).

Buffers. Buffer A: $40 \mathrm{mM}$ Tris- $\mathrm{HCl}, 1 \mathrm{mM}$ EDTA, $10 \%(\mathrm{w} / \mathrm{v})$ glycerol, $10 \mathrm{mM}$ dithiothreitol (DTT), 0.6 $\mathrm{mM}$ phenylmethylsulfonyl fluoride (PMSF) ( $\mathrm{pH} 7.4$ ); buffer B: buffer A supplemented with $10 \mathrm{mM}$ molybdate; buffer C: buffer B supplemented with $0.5 \mathrm{mM}$ bacitracin and $0.25 \mathrm{mM}$ leupeptin; buffer $\mathrm{D}$ : buffer $A$ supplemented with $1 \mathrm{mM}$ leupeptin; buffer $E$ : buffer D adjusted to $\mathrm{pH} 8.5$, with additionally $0.5 \mathrm{M} \mathrm{NaCl}$; buffer F: buffer A supplemented with $0.5 \mathrm{mM}$ bacitracin; buffer $\mathrm{G}$ : buffer $\mathrm{F}$ adjusted to $\mathrm{pH} 8.5$, with additionally $0.5 \mathrm{M} \mathrm{NaCl}$; buffer $\mathrm{H}$ : buffer $\mathrm{A}$ containing $0.4 \mathrm{M} \mathrm{KCl}$. Homogenization buffer I: prepared in essence according to Gorski et al. [10]: $10 \mathrm{mM}$ Hepes, 25 $\mathrm{mM} \mathrm{NaCl}, 0.15 \mathrm{mM}$ spermine, $0.5 \mathrm{mM}$ spermidine, 1 $\mathrm{mM}$ EDTA, $2 \mathrm{M}$ sucrose, $0.6 \mathrm{mM}$ PMSF, $10 \mathrm{mM}$ dithiotreitol, $10 \%(\mathrm{w} / \mathrm{v})$ glycerol (pH 7.6); buffer J; 0.5 $\mathrm{M}$ sucrose, further similar to buffer $\mathrm{I}$.

\section{Cells and tissues}

The LNCaP cell line (derived from a fast-growing colony of a lymph node carcinoma of the prostate [3]) was a gift from Dr. Horoszewicz (Buffalo, U.S.A.). The human prostatic tumor cell line PC3 [11] was kindly provided by Dr. van Steenbrugge, Erasmus University Rotterdam. Both cell types were cultured in RPMI 1640 medium (GIBCO) with added penicillin and streptomycin, supplemented with $7.5 \%(\mathrm{v} / \mathrm{v})$ heat-inactivated fetal calf serum (GIBCO) at $37^{\circ} \mathrm{C}$ in a humidified atmosphere of $5 \% \mathrm{CO}_{2}$ in air. The NHIK cell line (obtained from a human cervix carcinoma [12]) and genital skin (preputium) fibroblasts (fibroblasts were kindly provided by Dr. Degenhart, Erasmus University Rotterdam) were cultured in Eagles minimal essential medium (GIBCO) supplemented with $10 \%(\mathrm{v} / \mathrm{v})$ heatinactivated fetal calf serum (GIBCO) and non-essential amino acids (GIBCO). COS-1 cells were grown in Dulbecco's modified Eagle's medium (GIBCO) supplemented with $5 \%$ fetal calf serum. Further additions/ conditions were as described for LNCaP cells and PC3 cells. Media were changed every 3 or 4 days and cells were passaged once a week by plating out trypsinized cell suspensions. Experiments were done with passages 65-72 (LNCaP), 13-16 (NHIK), 14-16 (fibroblasts) and 45-47 (PC3).

The PC-EW human prostate tumor [13], grown in a nude mouse, was kindly provided by Dr. van Steenbrugge. The mouse was castrated 4 days before death. The tumor was kept on ice and used immediately for the competition assay.

Rat prostates were dissected from adult Wistar rats (substrain RP), castrated $24 \mathrm{~h}$ before killing.

\section{Methodology}

Cytosol preparations. LNCaP cells were cultured for 2 days in $5 \%$ dextran-charcoal stripped (stripped) serum. After trypsinization and addition of soybean trypsin inhibitor the cells were pelleted and homogenized in ice-cold buffer B with 15 strokes of a Potter-Elvehjem homogenizer at $900 \mathrm{rpm}$. The cytosol was prepared by centrifugation of the homogenate at $105000 \times g$ for $1 \mathrm{~h}$ at $2^{\circ} \mathrm{C}$.

Rat prostates from adult Wistar rats (sub-strain RP), castrated $24 \mathrm{~h}$ before killing, were homogenized at $0^{\circ} \mathrm{C}$ with a Thurrax homogenizer in buffer $B$, three times $4 \mathrm{~s}$, then centrifuged for $10 \mathrm{~min} 16300 \times \mathrm{g}$. The cytosol was prepared by centrifugation of the supernatant at $105000 \times g$ for $1 \mathrm{~h}$ at $2^{\circ} \mathrm{C}$.

The PC-EW tumor was homogenized in ice-cold buffer $\mathrm{C}$ by three bursts of $10 \mathrm{~s}$ with a Thurrax homogenizer, then centrifuged for $10 \mathrm{~min}$ at $16300 \times \mathrm{g}$. The cytosol was prepared by centrifugation of the homogenate at $105000 \times \mathrm{g}$ for $1 \mathrm{~h}$ at $2^{\circ} \mathrm{C}$. The supernatant was pre-incubated for $30 \mathrm{~min}$ with $500 \mathrm{nM}$ triamcinolone acetonide (a synthetic glucocorticoid with high affinity for the progesterone receptor) to occupy possible progesterone receptors $[14,15]$. This preparation was used for a competition assay. 
Isolation of LNCaP nuclei prior to incubation with steroids. Nuclei were isolated from LNCaP cells cultured for 2 or 3 days in medium without fetal calf serum or $5 \%$ stripped serum. Cells washed in phosphatebuffered saline were harvested by scraping in ice-cold homogenization buffer I. The cells were then homogenized with five strokes in a glass/Teflon homogenizer at $1100 \mathrm{rpm}$. Then half the volume of buffer $J$ was added and the suspension was centrifuged for $30 \mathrm{~min}$, $105000 \times \mathrm{g}$, at $2^{\circ} \mathrm{C}$. The pellet was rehomogenized in buffer I and half of the volume of buffer $J$ was added. The suspension was layered on a buffer I cushion and centrifuged for $30 \mathrm{~min} 105000 \times \mathrm{g}$ at $2^{\circ} \mathrm{C}$. Pelleted nuclei were resuspended in buffer $D$ and used for competition assays.

Scatchard analysis. LNCaP cell cytosol was incubated with increasing concentrations $(0.5-10 \mathrm{nM})$ of $\left[{ }^{3} \mathrm{H}\right]$ $\mathrm{R} 1881$ or $\left[{ }^{3} \mathrm{H}\right]$ progesterone at $4^{\circ} \mathrm{C}$ for $18 \mathrm{~h}$. In parallel incubations $1 \mu \mathrm{M}$ of unlabeled R1881 or progesterone was included to assess nonspecific binding. Bound and free steroids were separated using a dextran-coated charcoal assay and Scatchard analysis of the binding data was performed [12].

Competition assay. The resuspended nuclei were incubated for $18 \mathrm{~h}$ at $4{ }^{\circ} \mathrm{C}$ with $5 \mathrm{nM}\left[{ }^{3} \mathrm{H}\right] \mathrm{R} 1881$ in the presence of unlabeled steroids (R1881, dihydrotestosterone, progesterone and R5020 (a synthetic, non-metabolizable progestagen)), ranging from 0 to 100 -fold the concentration of the label. Nuclei were extracted in buffer $\mathrm{E}$ for $1 \mathrm{~h}$ at $4^{\circ} \mathrm{C}$ and centrifuged for $30 \mathrm{~min}$ at $14900 \times \mathrm{g}$. Separation of bound and unbound steroid was achieved by incubating the extract for $5 \mathrm{~min}$ with 1 vol. of $20 \mathrm{mM}$ pyridoxal phosphate in $10 \mathrm{mM}$ borate buffer ( $\mathrm{pH} \mathrm{8.1)}$ and precipitating proteins for 10 min with $10 \mathrm{vol}$. of protamine sulfate $(0.5 \mathrm{mg} / \mathrm{ml})$ [16]. After centrifugation $(15 \mathrm{~min}$ at $4000 \times \mathrm{g})$ pellets were washed, solubilized in soluene $\left(15 \mathrm{~min}\right.$ at $\left.60^{\circ} \mathrm{C}\right)$ and radioactivity was estimated in $10 \mathrm{ml}$ of the following mixture: Instagel (Packard) with $0.1 \%$ butylated hydroxytoluene $(\mathrm{w} / \mathrm{v})$ and $1 \%$ acetic acid $(\mathrm{v} / \mathrm{v}))$.

Competition studies with cytosols were essentially performed as described above for nuclear suspensions. For LNCaP cell cytosol and rat prostate cytosol the dextran-coated charcoal assay was used for separation of bound and unbound steroid.

Affinity labeling of the androgen receptor. $\mathrm{LNCaP}$ cells which had been kept on medium containing $5 \%$ stripped serum for 3 days were incubated with $10 \mathrm{nM}\left[{ }^{3} \mathrm{H}\right] \mathrm{R} 1881$ with or without $100 \mathrm{nM}$ unlabeled R5020 in serum-free medium for $1 \mathrm{~h}$ at $37^{\circ} \mathrm{C}$. In situ photolabeling of the receptor was then performed as described by van Laar et al. [17]. In brief: after two washes with ice-cold phosphate-buffered saline, the culture flasks were put on a $300 \mathrm{~nm}$ ultraviolet-transilluminator (UVP, U.S.A.) and the cells were irradiated for $2 \mathrm{~min}$. Then nuclei were isolated and extracted as described above. The amount of DNA in the pellet was measured to correct for the amount of cells in each incubation.

$S D S-P A G E$ of the affinity-labeled receptor. The androgen receptor was precipitated from the extract with $10 \%$ trichloroacetic acid overnight at $4^{\circ} \mathrm{C}$, then extensively washed with $10 \%$ trichloroacetic acid $(3 \times)$ and subsequently with ethyl acetate $(3 \times)$. The precipitate was dissolved in SDS sample buffer by boiling for 2 min and SDS-polyacrylamide gel electrophoresis using 8\% gels was done according to Laemmli [18]. The slab gel was then cut in $2 \mathrm{~mm}$ slices. The slices were dissolved in soluene (Packard) for $4 \mathrm{~h}$ at $45^{\circ} \mathrm{C}$ and radioactivity was estimated as described above. Parallel lanes were run with high-molecular-weight markers (Sigma, 29000-200 000).

Transfection of COS-1 cells. The androgen receptor expression plasmid pAR0 was constructed by ligating a 3037 bp BglII-PstI cDNA fragment, containing the complete androgen receptor protein coding region $[9,19]$, in the eukaryotic expression vector pBR328A + [20] using standard procedures.

COS-1 cells were grown in Dulbecco's modified Eagle's medium supplemented with $5 \%$ stripped fetal calf serum and antibiotics. Approx. $40 \%$ confluent cell cultures in $10 \mathrm{~cm}$ petri dishes were transfected with $10 \mu \mathrm{g}$ pAR0 and $10 \mu \mathrm{g}$ pTZ carrier plasmid using the calcium phosphate precipitation method [21]. $48 \mathrm{~h}$ after transfection, cells were used for the steroid binding assay.

Competition studies with intact cells. Competition studies were performed with LNCaP cells, PC3 cells, NHIK cells, fibroblasts and with COS-cells containing the transfected cDNA of the human androgen receptor. The cells were kept on $5 \%$ stripped serum containing medium for 1-3 days and wahsed two times with phosphate-buffered saline prior to the incubations with the steroids. The cells were incubated for $1 \mathrm{~h}$ at $37^{\circ} \mathrm{C}$ with $10 \mathrm{nM}$ tritiated R1881 with or without 100 -fold unlabeled R1881 to assess nonspecific binding. R5020 was used as a competitor at 10- or 100-fold the molar concentration of the labeled R1881. After two washes with ice-cold phosphate-buffered saline the cells were harvested by scraping in buffer $F$ and centrifugated at $800 \times g$. Cell pellets were homogenized by 6 strokes with a glass/Teflon homogenizer, followed by $10 \mathrm{~min}$ centrifugation $(800 \times g), 5$ min incubation in buffer $F$ containing $0.2 \%(\mathrm{v} / \mathrm{v})$ Triton $\mathrm{X}-100,10 \mathrm{~min}$ centrifugation $(800 \times g)$, resuspension in buffer $F$ and a final centrifugation step. Pelleted nuclei were extracted in buffer $\mathrm{G}$ for $1 \mathrm{~h}$ at $4^{\circ} \mathrm{C}$. Part of the extract was used for protamine sulfate precipitation of the receptor as described under competition assay, part of it was analyzed on a $10-30 \%$ sucrose gradient in buffer $\mathrm{H}[22] .{ }^{14} \mathrm{C}$ labeled bovine serum albumin $(4.6 \mathrm{~S})$ and $\left[{ }^{14} \mathrm{C}\right]$ ovalbumin $(3.6 \mathrm{~S})$ were used as sedimentation markers. 
After $20 \mathrm{~h} 400000 \times \mathrm{g}$ centrifugation at $2^{\circ} \mathrm{C}$ the gradients were collected in fractions and assayed for radioactivity.

After excretion of the nuclei, the pellets were dissolved in $1 \mathrm{M} \mathrm{NaOH}$ and used for counting the amount of non-extractable [ $\left.{ }^{3} \mathrm{H}\right] \mathrm{R} 1881$-bound receptors by scintillation counting.

DNA measurements DNA content of the extracted nuclei was measured according to Hinegardner [23].

\section{Results}

\section{Androgen receptor in cytosol fractions}

In preliminary experiments we determined the binding characteristics of androgen receptors in the cytosol fraction obtained from $\mathrm{LNCaP}$ cells for dihydrotestosterone, for the synthetic ligand R1881 and for progesterone. The binding affinity for dihydrotestosterone and for R1881 ( $\left.K_{\mathrm{d}} 0.4 \mathrm{nM}\right)$ was higher than the affinity for progesterone $\left(K_{\mathrm{d}} 3.9 \mathrm{nM}\right)$, but the number of binding sites was about equal for all three ligands. R1881 binds to both androgen and progesterone receptors with equal affinity [14], but immunological data showed that progesterone receptors are absent in LNCaP cells [6]. The non-metabolizable ligand R1881 was therefore preferred as androgen receptor ligand in subsequent studies.

The steroid binding specific of the androgen receptor in cytosol obtained from LNCaP cells was compared with the specificity of receptors from two other sources: rat prostate and the transplantable human prostate tumor PC-EW (Table I). In LNCaP cells the affinities of the receptor for both progesterone and R5020 (a synthetic, non-metabolizable progestagen), are much higher then in both PC-EW tumor cells and in rat

\section{TABLE I}

Relative binding affinities of different steroids for the androgen receptor in cytosol fractions of rat prostate, PC-EW cells and LNCaP cells

Cytosols obtained from rat prostate, PC-EW tumor and LNCaP cells were used for competition assays as described in the Experimental section. The relative binding affinity (RBA) is expressed in $\%$ as the ratio of the amounts of non-labeled R1881 and competing steroid which are needed for $50 \%$ inhibition of binding of tritiated R1881. The RBA for R1881 was set at $100 \%$ (n.d., not determined).

\begin{tabular}{lccc}
\hline Competitor & \multicolumn{2}{l}{ RBA value } & \\
\cline { 2 - 4 } & rat & PC-EW & LNCaP \\
& prostate & cells & cells \\
\hline R1881 & 100 & 100 & 100 \\
Dihydrotestosterone & 54 & 83 & 88 \\
Testosterone & 12 & n.d. & 25 \\
R5020 & n.d. & 0.3 & 8.4 \\
Progesterone & 0.1 & 0.3 & 17 \\
Estradiol & 0.2 & n.d. & 2.4 \\
Triamcinolone acetonide & $<0.1$ & n.d. & $<0.1$ \\
\hline
\end{tabular}

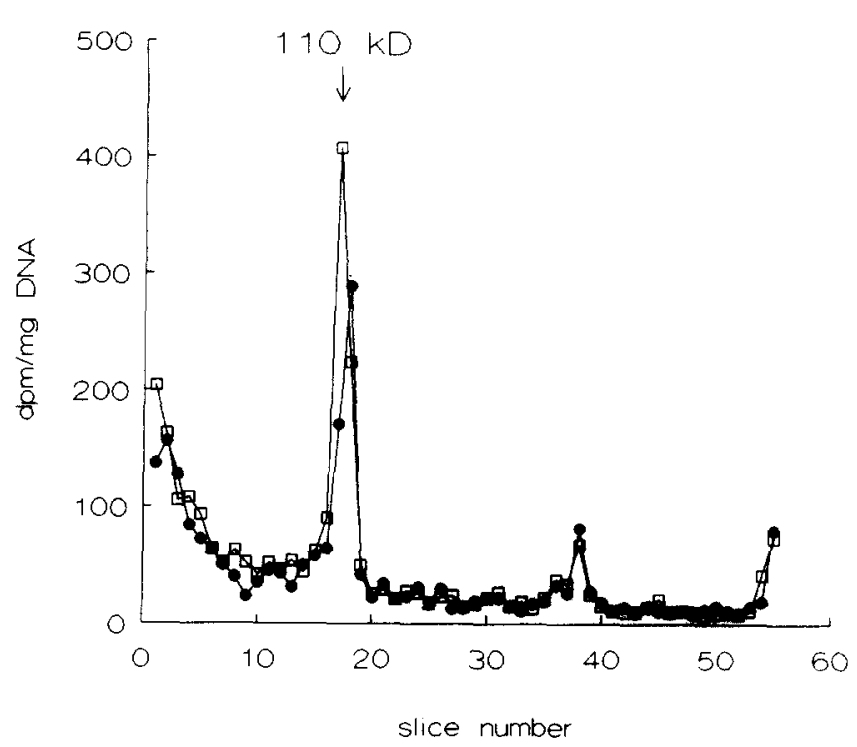

Fig. 1. SDS-polyacrylamide gel electrophoresis profiles of $\left[{ }^{3} \mathrm{H}\right] \mathrm{R} 1881$ affinity-labeled nuclear androgen receptor of $\mathrm{LNCaP}$ cells labeled at $37^{\circ} \mathrm{C}$ in the absence ( $\square$ ) and presence ( $\bullet$ ) of 10 -fold excess of R5020.

prostate. In addition, the receptor obtained from the LNCaP cells showed considerable affinity for estradiol.

The synthetic glucocorticoid triamcinolone acetonide has been used in assays for estimation of androgen receptors in the presence of progesterone receptors $[14,15]$. It binds to progesterone receptors but not to androgen receptors. The very low affinity of triamcinolone acetonide for the receptor in LNCaP cytosol (Table I) provides additional evidence that no progesterone receptors are present.

Quality of androgen receptor preparations obtained from the cell nucleus

The aim of these studies was to isolate a pure preparation of intact nuclei containing the receptor in ligand-free form and not degraded by proteolytic enzymes (i.e., present in the native $99 \mathrm{kDa}$ form).

The nuclear preparation obtained by sedimentation through a heavy sucrose cushion was free of cytoplasmic contaminants, cellular debris and intact cells, as monitored by phase contrast microscopy. The activity of the cytoplasmic marker enzyme lactate dehydrogenase in these preparations was low (less than $0.2 \%$ of that of intact cells), indicating that no intact cells were present and cytoplasmic contaminations are minimal.

The moleculalr size and intactness of the nuclear receptor was estimated by SDS-polyacrylamide electrophoresis after photoaffinity labeling of the receptor with R1881 (Fig. 1). One major peak is seen in these preparations, approximately at the position of $110 \mathrm{kDa}$, in agreement with previous studies [17] which also showed this position on SDS gels for the native $99 \mathrm{kDa}$ form [9] of the receptor. Proteolytic breakdown of the receptor is therefore minimal. 
Fig. 1 also shows that labeling of receptors in the presence of 10-fold excess of the synthetic progestagen R5020 results in a decrease of covalently labeled receptors (77\% of control). This decrease in binding of tritiated R1881 to the androgen receptor, in the presence of R5020 illustrates the high affinity of the androgen receptor for R5020.

The isolation procedure of nuclei in buffers containing spermine and spermidine and a high concentration of sucrose, had proven to be useful for the isolation of rat liver nuclei, containing tissue specific transcription factors [10]. Using this strategy, we found 3000 binding sites for R1881 per nucleus; when the cells were kept free from ligand prior to the isolation of the nuclei. The amount of binding sites for R1881 typically increased to 20000 sites per nucleus when the cells were preincubated with ligand.

\section{Binding specificity of receptors in the isolated nucleus}

LNCaP cells were grown on steroid-depleted medium and nucli which contained unoccupied receptors were isolated. The results of competition studies for nuclei incubated at $4^{\circ} \mathrm{C}$ with $\mathrm{R} 1881$, dihydrotestosterone, progesterone and R5020 are shown in Fig. 2. At a relatively small excess of the competing steroids, the binding of labeled R1881 is considerably decreased. The nuclear receptor clearly has a high affinity not only for R1881 and dihydrotestosterone but also for progesterone and R5020 (The relative binding affinities for dihydrotestosterone, progesterone and R5020 are respectively $135 \%, 57 \%$ and $13 \%$ of the affinity for R1881).

Excess non-radioactive dihydrotestosterone reduced the amount of labeled R1881 bound to the receptors to very low values (Fig. 2B), indicating that all R1881 is bound to androgen receptors. The glucocorticoid triamcinolone acetonide (not shown) did not compete for the nuclear binding sites, in agreement with the results obtained with cytosolic receptor preparations described above.

The steroid binding specificity of the transformed androgen receptor in different cell types

In the next series of experiments, the binding specificity of the transformed (DNA-binding form) androgen receptor was estimated in intact cells which were incubated for $1 \mathrm{~h}$ at $37^{\circ} \mathrm{C}$ with different steroids. Two different non-metabolizable ligands were used for comparison of the binding specificity: the progestagen R5020 and the androgen receptor ligand R1881. For this study receptors in LNCaP cells were compared with receptors in the human tumor PC3 and NHIK cells, in normal human fibroblasts, and in COS cells in which the human androgen receptor cDNA was expressed. These cells do not contain progesterone receptors $[11,12,24]$.
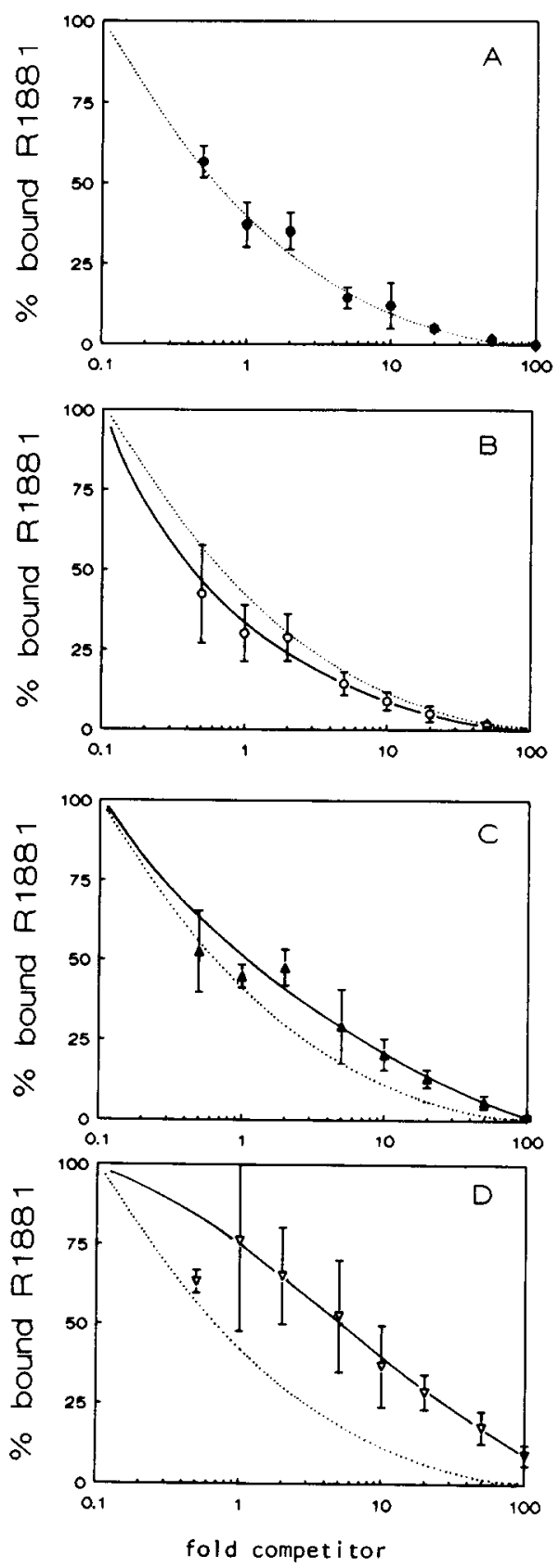

Fig. 2. Competitive binding curves of different steroids for the nonoccupied androgen receptor in intact isolated nuclei from $L N C a P$ cells at $4^{\circ} \mathrm{C}$. The given values are means \pm S.D. of three separate experiments. The curve for R1881 (dotted line) is shown in all four panels. (A) R1881 (๑); (B) dihydrotestosterone (O); (C) progesterone (A); (D) R5020 ( $\nabla$ ).

Fig. 3 shows the amounts of $\left[{ }^{3} \mathrm{H}\right] \mathrm{R} 1881$ in nuclear extracts obtained from the different cells, incubated in the presence of competing R5020. In the presence of a 100-fold molar excess of unlabeled R5020, the labeling of the receptors was significantly lower for $\mathrm{LNCaP}$ cells than for the other cells: $0.01>P>0.002$ (Student's $t$-test), when compared with NHIK cells, and $p<0.001$ when compared with the other cells. We also observed some variation in receptor labeling for the other cells. 
Only between the fibroblasts and the COS cells this was just significant $(0.05>P>0.02)$.

In Fig. 4 the results of sucrose density gradient centrifugation of the labeled nuclear extracts for LNCaP and NHIK cells are shown. The amount of label recovered from the peak fractions of the gradients, was identical to the amount of label found after protamine sulfate precipitation of the nuclear extracts. This indicates that all receptors present in the extracts are precipitated in the protamine sulfate assay.

The amount of label extracted from the nuclei varied between $41 \%$ and $73 \%$ for the different cells. For the residual, non-extracted receptors, the results of the competition studies were similar to those presented in Fig. 3. The low amount of $\left[{ }^{3} \mathrm{H}\right] \mathrm{R} 1881$ extracted from LNCaP cell nuclei, in the presence of R5020, as observed above, is therefore not due to an R5020-dependent change in extraction efficiency of the binding sites in the nuclear fraction. In fact, the sum of extractable and non-extractable values gave results similar to those presented in Fig. 3.

\section{Discussion}

The results in the present study show that the androgen receptor of the prostatic cell line LNCaP has

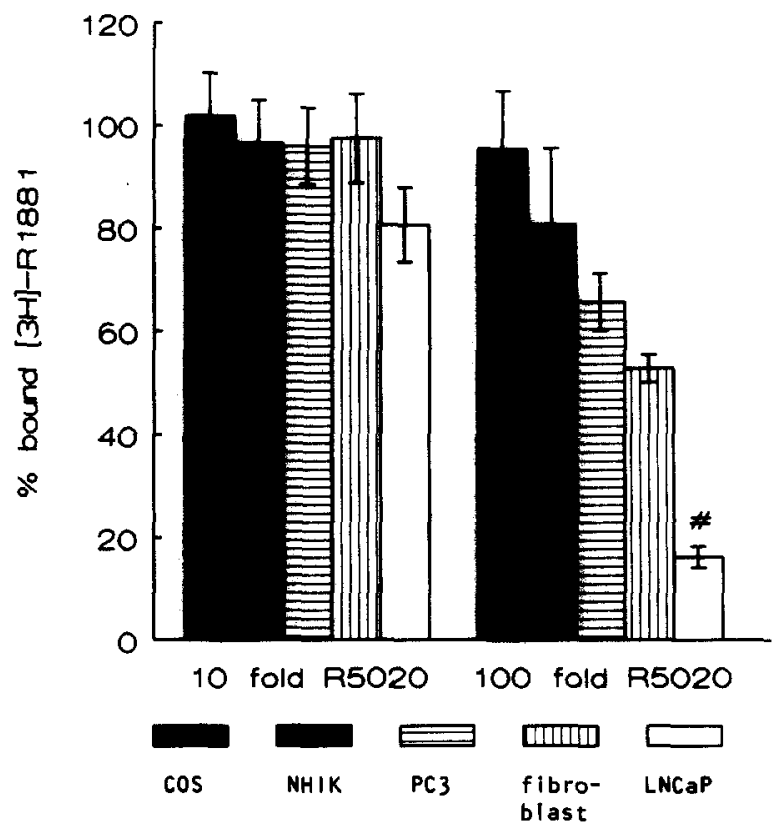

Fig. 3. Competition of the progestagen R5020 for androgen receptor binding sites in different cell types. Intact tumor cells (LNCaP, NHIK and PC3), normal human skin fibroblasts and COS cells transfected with the human androgen receptor were incubated at $37^{\circ} \mathrm{C}$ with $\left.{ }^{3} \mathrm{H}\right] \mathrm{R} 1881$ and a 10 - or 100 -fold molar excess of unlabeled R5020. Receptors were extracted from the nuclei as described in the Experimental section. The amount of specific $\left[{ }^{3} \mathrm{H}\right] \mathrm{R} 1881$ binding/mg DNA in the absence of competitor (R5020) was set at 100\%. The values are means \pm S.E. of three (NHIK, PC3, COS cells and fibroblasts) or four (LNCaP cells) separate experiments.
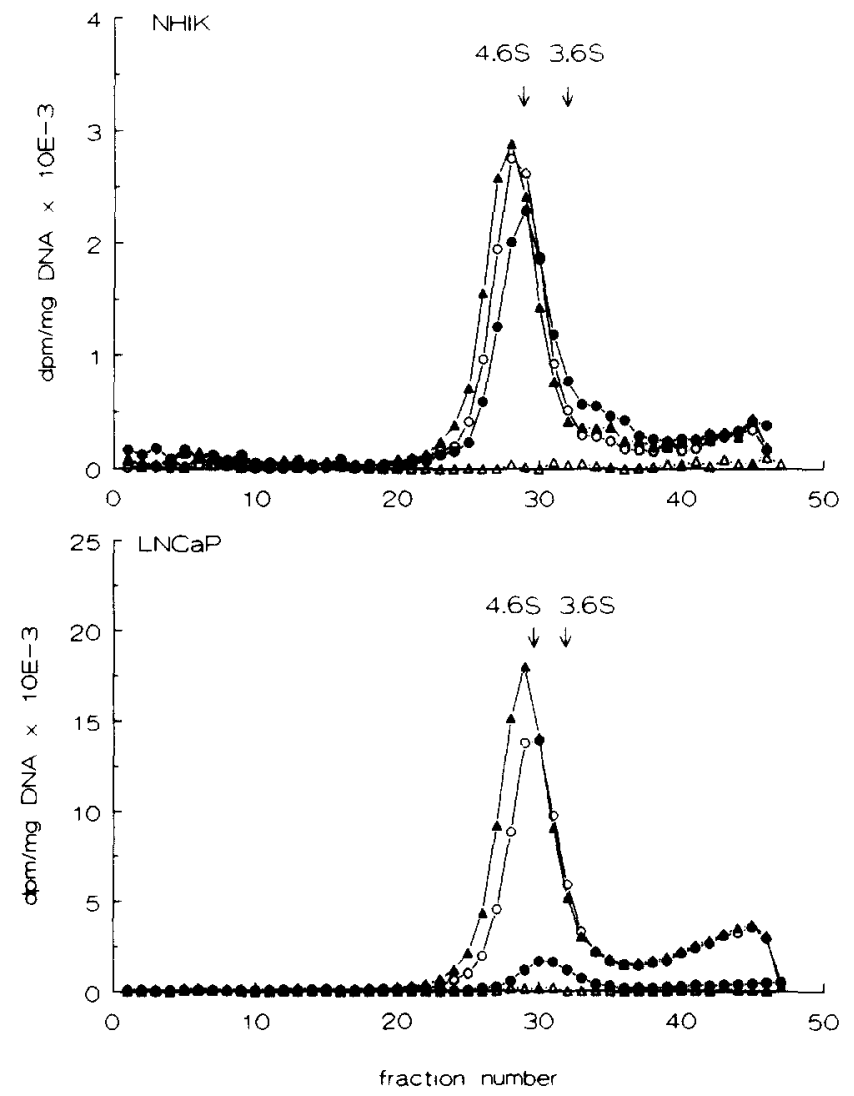

Fig. 4. Sucrose density-gradient centrifugation of androgen receptors extracted from nuclei of LNCaP and NHIK cells. Nuclei were isolated and extracted from cells incubated with $10 \mathrm{nM}\left[{ }^{3} \mathrm{H}\right] \mathrm{R} 1881$ alone $(\Delta)$, or in the presence of 100-fold unlabeled R1881 ( $\Delta$ ), 10-fold R5020 (O) or 100-fold R5020 (•).

a broad specificity. In addition to androgens, especially progestagens are bound with high affinity. The results also show that the progestagen binding capacity of the LNCaP cells was not due to the presence of progesterone receptors. This observation is in agreement with immunological data from previous studies which showed that progesterone receptors are absent [6] and that only androgen receptors are present in $\mathrm{LNCaP}$ cells [8].

The binding affinity of the androgen receptor in LNCaP cells was studied with two synthetic nonmetabolizable ligands: R1881, a steroid with equal affinity for androgen receptors and progesterone receptors [14] and generally used in androgen receptor binding studies [25], and R5020, a progestagen with a very low affinity for androgen receptors [26]. Receptors were labeled at $4^{\circ} \mathrm{C}$ to study the untransformed (non-DNAbinding) form of the receptor and at $37^{\circ} \mathrm{C}$ to study the transformed (DNA-binding) form of the receptor.

The results obtained with the cytosolic fractions of LNCaP cells, rat prostate and PC-EW tumor cells strongly indicate that the binding specifity of the androgen receptor in LNCaP cells is abnormal. In further studies the receptors were isolated from purified nuclei to exclude an unusual binding specificity either 
TABLE II

Relative binding affinities of different steroids for the androgen receptor in different sources: Literature data

Relative binding affinities (RBA) of some steroids for the androgen receptor in different cell types, calculated as described in the legend of Table I (n.d.: not determined). Data were obtained from:

(1) Asselin et al., hypertrophic human prostate cytosol, incubated at $0-4^{\circ} \mathrm{C}[14]$.

(2) Asselin et al., rat ventral prostate cytosol, incubated at $0-4^{\circ} \mathrm{C}$ [7].

(3) Bergink et al., human breast cancer cells MCF-7 cytosol, incubated at $4^{\circ} \mathrm{C}$ [39].

(4) Bergink et al., MCF-7 cells, whole cell assay, incubated at $37^{\circ} \mathrm{C}$ [39].

(5) Brown et al., human genital skin fibroblasts, whole cell assay, incubated at $37^{\circ} \mathrm{C}[24]$.

\begin{tabular}{lrrrrrr}
\hline & \multicolumn{6}{l}{ RBA value } \\
\cline { 2 - 7 } & Data from: & 1 & 2 & 3 & 4 & \multicolumn{1}{l}{5} \\
\hline R1881 & 100 & 100 & 100 & 100 & 100 \\
Dihydrotestosterone & 42 & 61 & 100 & 89 & 54 \\
Testosterone & 9 & 36 & 33 & 34 & n.d. \\
Progesterone & 2 & $<1$ & 5 & 0.5 & 0.6 \\
R5020 & $<1$ & $<1$ & n.d. & n.d. & n.d. \\
Estradiol & $<1$ & $<1$ & n.d. & n.d. & 0.8 \\
Triamcinolone acetonide & $<1$ & n.d. & n.d. & n.d. & 0.3 \\
\hline
\end{tabular}

due to contaminations of the cytosol with low-affinity binding proteins or to formation of proteolytic fragments of the receptor. Low-affinity binders for estrogens and other steroids have previously been determined in several tissues [27]. Rapid breakdown of androgen receptors has been shown for receptors in prostate tissue [28] and an effect in steroid binding can not be excluded. The androgen receptors which were obtained from the purified nuclei were intact. The photoaffinity-labeled receptor migrated as an $110 \mathrm{kDa}$ protein on SDS-PAGE as was found for the native 99 $k D a$ receptor $[9,17]$.

The non-transformed (non-DNA-binding) receptor in the purified nuclear fraction showed affnities for progesterone and the progestagen R5020 (42\% and 10\%, respectively, of dihydrotestosterone) which are extremely high for an androgen receptor compared to observations in other studies, see Table II.

The binding characteristics of the transformed, DNA-binding form of the androgen receptor was examined in intact cells at $37^{\circ} \mathrm{C}$. LNCaP cells were compared in this respect with $\mathrm{COS}$ cells containing the cloned human anhydrogen receptor, normal human skin fibroblasts and PC3 (prostate) and NHIK (cervix) human tumor cell lines. The affinity of the transformed androgen receptors for the progestagen R5020 in LNCaP cells was significantly higher than in the other cell systems, although the differences were less pronounced than for the non-transformed receptor form. This difference in affinity between transformed and non-transformed receptors might be due to a modulation of affinity of the receptor for steroids during the transformation process. Weichman and Notides [29] showed differences in ligand-receptor dissociation rates for the estrogen receptor in the transformed and untransformed form, and observed that the ratios of the dissociation rates for different steroids were not identical for these receptor forms. This might result in different affinity constants and relative binding affinities for a series of steroids depending on whether or not the assay conditions allow transformation of the receptor. Effects of assay conditions on steroid binding affinities, have been observed by Raynaud et al. [30] who showed differences in relative binding affinity of several steroids for different receptors depending on incubation time or temperature of the assay. A temperature-dependent change in affinity for estradiol was also shown for the human estrogen receptor containing an artefactual point mutation in the hormone-binding domain [31].

In the present study we used a mild procedure for isolation of nuclei [10] to prevent unoccupied androgen receptors from leaking out of the nucleus during isolation. The nuclei isolated from steroid-depleted cells, however, contained only $15 \%$ of the number of receptors found in the nuclei after incubation of the cells with androgens. Two explanations for this results are possible: either the unoccupied receptors do not reside in the nucleus, or the isolation procedure does not prevent leakage of androgen receptors out of the nucleus. Histochemical studies with specific antibodies against the androgen receptor are needed to obtain a definite answer about the localization of the unoccupied receptor. For estrogen and progestagen receptors a predominant nuclear localization was observed $[32,33]$, but unoccupied glucocorticoid receptors are also present in the cytoplasmic compartment [34,35].

Studies of cell systems containing androgen receptors with altered steroid specificity are scarce. Brown et al. [36] studied a mutant androgen receptor in human fibroblasts of certain patients with the androgen insensitivity syndrome and observed increased binding of progestagens. However, in contrast to our studies with LNCaP cells, also a decrease in affinity for androgens was found. Recently it was reported that the androgen receptor in these cells contained a mutation in the steroid binding domain, which resulted in replacement of valine in the normal sequence with a methionine in the mutated androgen receptor gene [37]. The changed binding pattern of the $\mathrm{LNCaP}$-cell androgen receptor could be due to a mutation in the steroid binding domain, although it might also be envisaged that posttranscriptional processing of the receptor is changed in the tumor cell (e.g., by phosphorylation).

If an abnormal binding pattern of steroids to a receptor is found, ligands that normally do not bind and transform the receptor, might lead to enhanced transcription of specific genes, but only when all subse- 
quent steps towards gene activation are effectuated in a comparable way as by the natural ligand. The growth effects on LNCaP cells of progestagens described by Schuurmans et al. [6] indicate that some progestagens indeed have the capacity to transform the receptor and subsequently induce growth stimulatory effects. In addition, it has been recently shown that $\mathrm{LNCaP}$ cells behave aberrantly with respect to the response to antiandrogens. Both Wilding et al. [38] and studies in our laboratory (unpublished observations) showed increase in growth rate and excretion of prostate specific acid phospatase with different anti-androgens (cyproterone acetate and flutamide derivatives). It is tempting to speculate that there is a relationship between the abnormal steroid-binding specificity of the androgen receptors and the androgenic actions of progestagens and anti-androgens in LNCaP cells.

\section{Acknowledgements}

We wish to thank Dr. van Steenbrugge for providing us with the PC-EW prostate tumor and the PC3 cell line, and Dr. Degenhart for providing us with the human preputium skin fibroblasts.

\section{References}

1 Grody, W.W., Schrader, W.T. and O'Malley, B.W. (1982) Endocr. Rev. 3, 141-163.

2 Parker, M. (1983) Nature 304, 687-688.

3 Horoszewicz, J.S., Leong, S.S., Kawinski, E., Karr, J.P., Rosenthal, H., Ming Chu, T., Mirand, E.A. and Murphy, G.P. (1983) Cancer Res. 43, 1809-1818.

4 Berns, E.M.J.J., De Boer, W. and Mulder, E. (1986) The Prostate 9, 247-259.

5 Schulz, P., Bauer, H.W. and Fittler, F. (1985) Biol. Chem. 336, 1033-1039.

6 Schuurmans, A.L.G., Bolt, J., Voorhorst, M.M., Blankenstein, M.A. and Mulder, E. (1988) Int. J. Cancer 42, 917-922.

7 Asselin, J., Labrie, F., Gourdeau, Y., Bonne, C. and Raynaud, J.P. (1976) Steroids 28, 449-459.

8 Van Laar, J.H., Voorhorst-Ogink, M.M., Zegers, N.D., Boersma, W.J.A., Claasen, E., van der Korput, J.A.G.M., Ruizeveld de Winter, J.A., Van der Kwast, Th.H., Mulder, E., Trapman, J. and Brinkmann, A.O. (1989) Mol. Cell. Endocrinol. 67, 29-38.

9 Trapman, J., Klaasen, P., Kuiper, G.G.J.M., Van der Korput, J.A.G.M., Faber, P.W., Van Rooij, H.C.J., Geurts van Kessel, A., Voorhorst, M.M., Mulder, E. and Brinkmann, A.O. (1988) Biochem. Biophys. Res. Commun. 153, 241-248.

10 Gorski, K., Carneiro, M. and Schibler, U. (1986) Cell 47, 767-776.

11 Kaighn, M.E., Shankar, Narayan, K., Ohnuki, Y., Lechner, J.F. and Jones, L.W. (1979) Invest. Urol. 17, 16-23.
12 Mulder, E., Peters, M.J., De Vries, J., Van der Molen, H.J., Ostgaard, K., Eik-Nes, K.B. and Oftebro, R. (1978) Mol. Cell. Endocrinol. 11, 309-323.

13 Hoehn, W., Wagner, M., Riemann, J.F., Hermanek, P., Williams, W., Walter,, R. and Schrueffer, R. (1984) Prostate 5, 445-452.

14 Asselin, J., Melançon, R., Gourdeau, Y., Labrie, F., Bonne, C. and Raynaud, J.P. (1979) J. Steroid Biochem. 10, 483-486.

15 Zava, D., Landrum, B., Horwitz, K. and McGuire, W. (1979) Endocrinology 104, 1007-1012.

16 Mulder, E., Vrij, L. and Foekens, J.A. (1981) Mol. Cell. Endocrinol. 23, 283-296.

17 Van Laar, J.H., Bolt-de Vries, J., Voorhorst-Ogink, M.M. and Brinkmann, A.O. (1989) Mol. Cell. Endocrinol. 63, 39-44.

18 Laemmli, U.K. (1970) Nature 227, 680-685.

19 Faber, P.W., Kuiper, G.G.J.M., Van Rooij, H.C.J., Van der Korput, J.A.G.M., Brinkmann, A.O. and Trapman, J. (1989) Mol. Cell. Endocrinol. 61, 257-262.

20 Van Heuvel, M., Bosveld, I.J., Mooren, A.T.A., Trapman, J. and Zwarthoff, E.C. (1986) J. Gen. Virol. 67, 2215-2222.

21 Chen, C. and Okayama, H. (1987) Mol. Cell. Biol. 7, 2745-2752.

22 De Boer, W., Bolt, J., Brinkmann, A.O. and Mulder, E. (1986) Biochim. Biophys. Acta 889, 240-250.

23 Hinegardner, R.T. (1976) Anal. Biochem. 72, 248-254.

24 Brown, T.R., Rothwell, S. and Migeon, C.J. (1981) J. Steroid Biochem. 14, 1013-1022.

25 Robel, P., Eychenne, B., Blondeau, J.P., Baulieu, E.E. and Hechter, O. (1985) The Prostate 6, 255-267.

26 Ojasoo, T. and Raynaud, J.P. (1978) Cancer Res. 38, 4186-4198.

27 Panko, W.B., Watson, C.S. and Clark, J.H. (1981) J. Steroid Biochem. 14, 1311-1316.

28 Mulder, E. and Brinkmann, A.O. (1985) in Molecular Mechanism of Steroid Hormone Action (Moudgil, V.K., ed.), pp. 563-585, Walter de Gruyter, Berlin.

29 Weichman, B.M. and Notides, A.C. (1980) Endocrinology 106, 434-439.

30 Raynaud, J.P., Bouton, M.M., Moguilewsky, M., Ojasoo, T., Philibert, D., Beck, G., Labrie, F. and Mornon, J.P. (1980) J. Steroid Biochem. 12, 143-157.

31 Tora, L., Mullick, A., Metzger, D., Ponglikitmongkol, M., Park, I. and Chambon, P. (1989) EMBO J. 8, 1981-1986.

32 King, W.J. and Greene, G.L. (1984) Nature (Lond.) 307, 745-747.

33 Gasc, J.M., Renoir, J.M., Radanyi, C., Joab, I., Tuohima, P. and Baulieu, E.E. (1984) J. Cell. Biol. 99, 1193-1201.

34 Wikström, A.C., Bakke, O., Okret, S., Brönnegård, M. and Gustafsson, J.A. (1987) Endocrinology 120, 1232-1242.

35 Robertson, N.M., Kusmik, W.F., Grove, B.F., Miller-Diener, A., Webb, M.L. and Litwack, G. (1987) Biochem. J. 246, 55-65.

36 Brown, T.R., Maes, M., Rothwell, S.W. and Migeon, C.J. (1982) J. Clin. Endocrinol. Metab. 55, 61-69.

37 Lubahn, D.B., Brown, T.R., Simental, J.A., Higgs, H.N., Migeon, C.J. and French, F.S. (1989) in The Endocrine Society, 71st Annual Meeting, 1989, Seattle, Washington (Bell, L., ed.), pp. 178, The Endocrine Society, Bethesda.

38 Wilding, G., Chen, M. and Gelmann, E.P. (1989) The Prostate 14, 103-115.

39 Bergink, E., Van Meel, F., Turpijn, E. and Van der Vries, J. (1983) J. Steroid Biochem. 19, 1563-1570. 